\title{
SUPPORTING FAMILIES IN CORRECTING DYSLALIA IN CHILDREN
}

\author{
Aleksandra Siedlaczek-Szwed \\ Agata Jałowiecka-Frania \\ Akademia im. Jana Długosza w Częstochowie, Polska
}

\begin{abstract}
The text deals with issues related to the effective support of speech and language therapy for children with dyslalia. The effectiveness of speech and language stimulation is determined by a wide range of determinants. Individual predispositions, influences of educational environments, personality, professionalism, the scope of speech and language therapists' knowledge and abilities as well as a variety of methods used by them play an essential role. Dyslalia, which is one of the most frequent speech disorders, has a negative and significant impact on children's psychosocial functioning. Children's attitudes toward peers with speech articulation disorders not only seem to affect intellectual, cognitive and motivational processes, including perception, attention, memory, thinking, but also transform social behaviours. Therefore, the profound significance of the family's influence on the effectiveness of speech and language therapy for children with dyslalia has been emphasised. It is assumed that educational activities require planned, intentional and regular collaboration with various environments in order to achieve desired goals and shape comprehensive individual development.
\end{abstract}

Keywords: child's development support, compensation, deformation, dyslalia, early intervention, elision, substitution, therapeutic procedure.

\section{Introduction}

Speech defects are one of the most common speech disorders observed, among others, in improper construction and functioning of articulation organs, delayed speech development, aphasia, cerebral paralysis of children, intellectual disability or hearing damage (Sołtys-Chmielowicz, 2012). In the terminology of speech therapy and phonetic terminology, speech disorders are referred to as "dyslalia". Describing dyslalia as "speech defects" is also present in the European literature, eg. Czech, Slovak, German, Russian. In Polish literature the term "dyslalia" operates in two senses:

- descent, lighter form of alalia, or untrained speech, which is the result of cortical brain damage;

- a separate unit in the symptomatology classification of speech disorders (Minczakiewicz, 1997). 
Dyslalia, in understanding of Hanna Rodak, is a symptom of speech disorders referring to the articulatory aspect of language (Rodak, 2002). Grażyna Jastrzębowska understands dyslalia (synonyms: articulation disorders, speech defects, articulation defects, incorrect realisations of phonemes, the distortion of the substance of phonic plane segmentation) in terms of disorder implementation of peripheral phonemes, manifested by distortion, replacement or abandonment of speech sounds that result in abnormal spoken sound. (Jastrzębowska, 2003). According to Antoni Pruszewicz, referring to dyslalia as "mumbling", only covers disorders of central articulation for the changes of patterns of phonetic-phonology with the proper operation of the other functions of speech, for example: naming, comprehension, repetition, lexical resource, grammatical and syntactic structure (Pruszewicz, 1992). According to Agnieszka Hamerlińska-Latecka dyslalia is an articulation disorder having diverse aetiology and revealing the incorrect pronunciation of sounds or sounds as a result of elision, substitution, deformation or compensation (Hamerlińska-Latecka, 2012). Elision (mogilalia), is a lack of implementation of the phoneme in the form of separate sounds. It can take the full form when it relates to items pre-, inter- and post vocal or limited only to certain items (eg. word initial position), and the total - in the pursuit of the phoneme as zero phonetic and partial, the changes include a nearby vocalic segment or there appears noiseless segment instead of the phoneme. Substitution (paralalia) occurs in case of implementation of specific phonemes present in the execution of another phoneme, two phonemes of the general system are pronounced in the same way. A phoneme may be represented by several or even a dozen substitutes. Primarily changed phonemes are those called as "consonant", but also vocalic. Such form of defective speech appears as loose (facultative variant) or structural (combinatorial and lexical variant). In case of the optional variant, one of the two substitutes of the phoneme is realised in the onset, the other in the centre of a word and coda or it appears as first only in groups of consonants, the second one appears outside of these groups. When the lexical variant occurs, one of the substitutes is still in certain words, the second in other words. Deformation is the realisation of a particular phoneme that does not fit the realisation of this phoneme, as well as other phonemes. This includes sounds unusual for a phonetic system, including interdental sounds, side spirants, variously localised vibrational sounds. The most common are deformed "consonant" phonemes, but also a vocalic ones (Kania, 2001). Compensation means articulation while doing speech therapy, and it is about repeating the same, previously incorrectly spoken sounds with greater correctness, but still in a way that does not meet all the distinctive features due to the inability to eliminate the causes of incorrect pronunciation (HamerlińskaLatecka, 2012). 


\section{Dyslalia disorders and family support to stimulate the language development of the child}

The aetiology of articulation disorders refers to two groups of factors: exogenous (external) and endogenous (internal). The first one is related with negative patterns of environmental changes in family structure (eg. the emergence of younger siblings) and the intended or unconscious actions to support the articulation of previous periods of development. Endogenous factors include:

- anatomical changes of the articulatory apparatus;

- malfunction of speech organs;

- malfunctioning of phonic hearing;

- other difficulties relating to the central processing of speech, eg. the absence of appropriate representation of phonemes (or possible variants of sounds contained therein), words, slow access to individual lexical network, problems with planning sequence (Czaplewska, 2015).

In speech therapy practice, one cannot clearly separate the internal and external factors.

Among the various causes of dyslalia disorders one can therefore include:

1. Anatomical changes of articulation apparatus:

- improper tongue construction - macro-sound, too long or too short tongue, too thick, short under tongue frenulum;

- $\quad$ incorrect construction of the palate - too strongly arched, narrow hard palate, so-called. Gothic palate, cleft palate;

- malocclusion - open bite, overshot, undershot bite, overbite, crossbite;

- Dental anomalies - diastema, protrusion, retrusion, transient anomalies, eg. during replacement of teeth;

- $\quad$ third tonsil hypertrophy;

- polyps;

- nasal septum deviation;

- hypertrophy of the nasal mucosa.

2. Improper functioning of speech organs:

- low lips and tongue functioning;

- $\quad$ impaired work, muscle tension and adductors ligaments voice;

- difficulty in coordinating the work of vocal cords with the articulation of the base;

- impaired operation of shorting ring throat;

- $\quad$ lack of verticalisation language called: infantile swallowing.

3. Improper construction and functioning of hearing organ:

- distortion of hearing analysis and synthesis; 
- $\quad$ selective hearing loss;

- reduction of hearing (hearing loss, deafness);

- $\quad$ phonetic hearing impairment.

4. Improper speaking learning conditions:

- $\quad$ wrong speech examples;

- unwilling atmosphere, education conditions and parents' approach;

- lack of speech development stimulation.

5. Malfunction of the central nervous system (central dyslalia, central dyslalia appearing in the case of aphasia and dysarthria).

6. Mental substrate:

- lack of interest with the speech of others;

- feeling own statements as tiring, unsatisfactory and its reduction, resulting in disruption of normal development of speech (associative dyslalia).

7. Delayed psychomotor development (developmental dyslalia) and the child's emotional development (Jastrzębowska, 2003).

The most important etiological factors of dyslalia by H. Rodak are:

- phoneme hearing disorders hindering the auditory recognition of sounds;

- not paying attention to the pronunciation;

- $\quad$ reduced the level of intelligence;

- $\quad$ anatomical damage to peripheral organs of speech;

- the low efficiency of the speech organs;

- the organic diseases of the nervous system and paralysis around the medulla (Rodak 2002).

In the literature one can find different classifications of dyslalia, for example. Causal, qualitative, quantitative or qualitative phonic linguistics. Taxonomic diversity is a source of number of criteria, which are the base for the division, which is illustrated in the table below:

Conducting diagnostic procedure is the starting point for the development for an individual program of speech therapy. Treatment of speech disorders is made of complex actions aimed for eliminating irregularities of articulation and compensates for the dysfunction in both adults and children (Rodak, 2002). Its aim is to increase the intelligibility of speech (with substitutions), verbalisation aesthetics in both auditory and visual area(with deformities), but also remove any defective elements, calling attention of listeners (Sołtys-Chmielowicz, 2008). 
Table 1 Types of dyslalia taking into account different criteria of division

\begin{tabular}{|c|c|}
\hline DIVISION CRITERIA & TYPE OF DYSLALIA \\
\hline $\begin{array}{l}\text { Number of improper realised distinctive } \\
\text { character of phoneme }\end{array}$ & $\begin{array}{ll}\text { - } & \text { Simple Dyslalia } \\
\text { - } & \text { Complex Dyslalia }\end{array}$ \\
\hline Number of wrongly spoken vowels & $\begin{array}{ll}\text { - } & \text { Same kind dyslalia } \\
\text { - } & \text { Partial dyslalia } \\
\text { - } & \text { Many kinds dyslalia } \\
\text { - } & \text { Total dyslalia } \\
\end{array}$ \\
\hline Number of disrupted articulations spheres & $\begin{array}{l}\text { - } \quad \text { Monomorphic dyslalia } \\
\text { - } \quad \text { Polymorphic dyslalia }\end{array}$ \\
\hline Manner of improper realisation of sound & $\begin{array}{ll}\text { - } & \text { Mogilalia } \\
\text { - } & \text { Paralalia } \\
\text { - } & \text { Proper dyslalia }\end{array}$ \\
\hline $\begin{array}{l}\text { Name of vowel or vowels which are articulated } \\
\text { wrongly }\end{array}$ & $\begin{array}{l}\text { - } \text { Sigmatism } \\
\text { - Rotacism } \\
\text { - Kappacism } \\
\text { - Gammacism } \\
\text { - "Kiganie" } \\
\text { - "Giganie" } \\
\text { - Lambdacism } \\
\text { - Betacism } \\
\text { - Soundless pronunciation } \\
\text { - Rynolalia - nasal speech } \\
\text { - Palatolalia - inborn anatomic defects }\end{array}$ \\
\hline The length of wrongly spoken vocal line & $\begin{array}{ll}\text { - } & \text { Vowel dyslalia } \\
\text { - } & \text { Syllable dyslalia } \\
\text { - } & \text { Words dyslalia } \\
\text { - } & \text { Sentence dyslalia }\end{array}$ \\
\hline $\begin{array}{l}\text { Reoccurrence of wrong articulation in particular } \\
\text { communication situations }\end{array}$ & $\begin{array}{ll}\text { - } & \text { Constant dyslalia } \\
\text { - } & \text { Non-constant dyslalia }\end{array}$ \\
\hline $\begin{array}{l}\text { Vocal positions and phonetic neighbouring in } \\
\text { which the improper speech appears }\end{array}$ & $\begin{array}{ll}\text { - } & \text { Consequent dyslalia } \\
\text { - } & \text { Inconsequent dyslalia }\end{array}$ \\
\hline $\begin{array}{l}\text { The stage of solidification of improper } \\
\text { articulation }\end{array}$ & $\begin{array}{l}\text { - } \quad \text { Lingering dyslalia } \\
\text { - } \quad \text { Non-lingering dyslalia }\end{array}$ \\
\hline Origin of cause & $\begin{array}{ll}\text { - } & \text { Central dyslalia } \\
\text { - } & \text { Peripheral dyslalia } \\
\text { - } & \text { Autogenic dyslalia } \\
\text { - } & \text { A-social dyslalia } \\
\text { - } & \text { Environmental dyslalia } \\
\text { - } & \text { Coupled dyslalia }\end{array}$ \\
\hline Type of cause & $\begin{array}{ll}\text { - } & \text { Functional dyslalia } \\
\text { - } & \text { Organic dyslalia }\end{array}$ \\
\hline
\end{tabular}


Therapeutic procedure includes such areas as:

I. Therapy programme. Scope of programme:

1. Speech therapy procedures.

2. Strategies and methods of action.

3. Organisation of procedure.

II. Therapeutic procedure:

1. Organisation of therapy stages and its evaluation. Choice of resources and help.

2. Appropriate documentation.

3. Verification of diagnostic hypotheses.

4. Programme modification (Grabias, 2010/2011).

Anna Sołtys-Chmielowicz distinguishes, in case of dyslalia, three phases of corrective work:

1. Preparation phase - excercises which increase the ability of phonemic hearing, as well as motors of speaking organs.

2. The phase of forcing the sound with the use of various methods.

3. The phase of implementation, meaning using correct sound in various situational contexts (Sołtys-Chmielowicz, 2002).

On the other hand, Józef Surowaniec mentions such phases as:

- preparation phase which includes making contact with a patient and encouraging him to active participation in a therapy;

- the phase of shaping abilities and habits of proper vowel use, which was earlier pronounced wrong;

- the phase of abilities and habits development in the correct verbalisation in every communication situation and place (Surowaniec, 1993).

G. Jastrzębowska and Olga Pelc-Pękala, in the scope of articulation disorder, point out:

1. Preparation phase - a collection of actions which happen before the proper speech therapy work, which consists of various exercises that expedite articulation, breathing organs, and point out the rhythm and hearing abilities.

2. The phase of actual speech therapy - forcing a proper articulation of a disrupted vowel in an isolation.

3. The phase of embedding the forced sound, its stabilisation in a controlled speech - embedding vowel in: isolation, syllables, words in all possible positions (out loud, invoice, and outvote) and neighbouring phonetics, two-word expressions, sentences, short texts.

4. The phase of automatisation of the forced sound, its realisation in spontaneous speech - tearing it from speech fact awareness by 
embedding kinetic-movement examples and hearing auto-control (Jastrzębowska \& Pelc-Pękala, 2003).

As it seems, speech therapy hinders on the therapist exercises such as: security of the child, mental comfort and trust - providing attention, positivism, pointing out what is good in a child; marking development, changes which have been made and not the lack of abilities; choosing methods of work in the scope of passions and development level; shaping positive motivation to learn in, faith in ones own strengths and abilities, fighting difficulties - delicate persuasion, acceptance, stimulation strengthening, equivalent; pedagogical optimism and faith in child's abilities, noticing even the smallest achievements and strict cooperation with parents and teachers - their involvement in the therapeutic process.

Each pedagogical activity, in order to be effective and properly shaped overall individual development, forces planned, intentional and regular cooperation of various environments, as the education is about, on one side, direct influence on a person by supporting her in a natural and spontaneous development, and on the other, about influencing by consciously used actions (Smykowska, 2008). Development, which is emphasised by Anna Brzezińska (Brzezińska, 2004), including the language development, as a result of exchange between an identity and its surrounding, is determined not only by the own potential but also environmental resources, meaning directed actions taken by the society. Family support in a process of language development stimulation of a child, according to the needs reported by the parents (Mrugalska, 1999), should then consider:

- $\quad$ early, multidisciplinary diagnosis in a long term observation;

- common evaluation by the group of specialist the stimulation programme, rehabilitation or therapeutic ones and its complex realisation;

- $\quad$ providing exact directions in a scope of own work at home, including specially child's activities understanding and motivation to work, creating atmosphere which is good for child's state of mind;

- psychological help, especially in a scope of providing proper information and advice;

- possibility to make contact with other parents, who deal with similar problems.

Necessity for a multidisciplinary language development stimulation, raises from the understanding of speech therapy as a science, which not only is based on the achievements of other fields, but also integrates their studies' results. Beata Cytowska (Cytowska, 2006), by analysing the aspects of early intervention and support for a small child development, notices that this area of action is within a scope of interest of many disciplines: medicine, psychology, neurology or social 
pedagogy. Contemporarily, as a result of EU directives and the changes in law regulations, in a scope of early intervention and early help, it is observed that there are two tendencies concerning: direct involvement of health service, school, social studies, psychology, as well as stepping away from intervention focused only on a child and concentring on an intervention focused on family and environment (Prysak \& Wrona, 2013).

The team of professionals to help the family in supporting child development are: educator, with qualifications appropriate for the type of disability of a young man (oligophrenic therapist, optitian, deaf educator), a psychologist, a speech therapist, and other specialist depending on the needs of a child. Jacek Zalewski (Zalewski, 2009) calls for a creation within a scope of territorial government, an assistant for the family with disabilities, who would make a function of guide in a present reality, by pointing optimal ways to deal with unexpected or problematic situations. The first meeting with assistant would have been on the new borns award, and in the effect of the actions taken by the therapist, the family activity should increase. It should be mentioned that early intervention and early support of development consider the disabled children from the very first moments of their lives, or those who are endangered with disability, with genetic disorders, too early born or in the high risk groups. However, the professional help is not only needed for the parents of such child, but also for those who have, so called, healthy children. As not always they possess exact level of knowledge and abilities in a scope of care, education or stimulation of various areas of young man functioning. The meaning of supporting process is focused mainly on parents, on what should they achieve, so learning how to became a better mother or father (Kwaśniewska, 2009). Stimulation of child's language development is focused mainly around the family home, then it needs to be conducted with presence of professionalises, among whom one should mention: speech therapist, psychologist, teacher, and the paediatrician. It would have been perfect to create in every clinic a group of the above mentioned specialists, the purpose of which would be directing and strengthening actions in order to learn language properly, which is actually a fundamental point of school successes and then professional ones, some kind of a language code which determines human's live possibilities.

\section{References}

Brzezińska, A. (2004). Społeczna psychologia rozwoju. Wydanie II. Warszawa: Wydawnictwo Naukowe „Scholar”.

Cytowska, B. (2006). Idea wczesnej interwencji i wspomagania rozwoju małego dziecka. In: Cytowska, B., Winczura, B. (Eds.) Wczesna interwencja $i$ wspomaganie rozwoju małego dziecka (pp. 15-26). Kraków: Oficyna Wydawnicza „Impuls”. 
Czaplewska, E. (2015). Diagnoza zaburzeń rozwoju artykulacji. In: Czaplewska, E., Milewski, S. (Eds.) Diagnoza logopedyczna. Podręcznik akademicki (pp. 65-120). Sopot: Gdańskie Wydawnictwo Psychologiczne.

Grabias, S. (2010/2011). Logopedia - nauka o biologicznych uwarunkowaniach języka i zachowaniach językowych. Logopedia, 39/40, 9-34.

Hamerlińska-Latecka, A. (2012). Dyslalia. Psychospołeczny aspekt terapii logopedycznej. Bydgoszcz: Wydawnictwo Uniwersytetu Kazimierza Wielkiego.

Jastrzębowska, G., \& Pelc-Pękala, O. (2003). Diagnoza i terapia zaburzeń artykulacji (dyslalii). In: Gałkowski, T., Jastrzębowska, G. (Eds.) Logopedia - Pytania $i$ odpowiedzi. Podręcznik akademicki, t. 2: Zaburzenia komunikacji językowej u dzieci i osób dorostych (pp. 403-429). Wydanie II zmienione i poszerzone. Opole: Wydawnictwo Uniwersytetu Opolskiego.

Jastrzębowska, G. (2003). Dyslalia. In: Gałkowski, T., Jastrzębowska, G. (Eds.) Logopedia Pytania i odpowiedzi. Podręcznik akademicki, t. 2: Zaburzenia komunikacji językowej u dzieci i osób dorostych (pp. 143-175). Wydanie II zmienione i poszerzone. Opole: Wydawnictwo Uniwersytetu Opolskiego.

Kania, J. T. (2001). Szkice logopedyczne. Wydanie II poprawione. Lublin: Polskie Towarzystwo Logopedyczne. Zarząd Główny.

Kwaśniewska, G. (2009). Rola i kompetencje specjalistów w procesie wczesnego wspomagania rodziny dziecka z niepełnosprawnością. In: Brejak, W., Zabłocki, K.J. (Eds.) Wczesna diagnoza $i$ wspomaganie rozwoju dziecka z dysfunkcjami (pp. 62-70). Warszawa: Stowarzyszenie Dobra Wola OPP.

Minczakiewicz, E. M. (1997). Mowa-Rozwój-Zaburzenia-Terapia. Kraków: Wydawnictwo Naukowe WSP.

Mrugalska, K. (1999). Czy rodzice i profesjonaliści mogą być sojusznikami? In: Olechnowicz, H. (Eds.) $U$ źródet rozwoju dziecka. O wspomaganiu rozwoju prawidłowego $i$ zakłóconego (pp. 38-50). Warszawa: Wydawnictwa Szkolne i Pedagogiczne.

Pruszewicz, A. (1992). Zaburzenia artykulacji. In: Pruszewicz, A. (Eds.) Foniatria kliniczna (pp. 242-248). Warszawa: Państwowy Zakład Wydawnictw Lekarskich.

Prysak, D., \& Wrona, S. (2013). Działania profilaktyczne wczesnej interwencji w kształtowaniu prawidłowych relacji społecznych dorosłych osób niepełnosprawnych. In: Baran, J., et al. (Eds.) Teoria $i$ praktyka oddziaływań profilaktyczno-wspierających rozwój osób $z$ niepetnosprawnościa (pp. 11-23). Kraków: Oficyna Wydawnicza „Impuls”.

Rodak, H. (2002). Terapia dziecka z wada wymowy. Warszawa: Wydawnictwa Uniwersytetu Warszawskiego.

Skorek, E. M. (2001). Oblicza wad wymowy. Warszawa: Wydawnictwo Akademickie „Żak”.

Smykowska, D. (2008). Wspótpraca szkoty z rodzina $w$ zaspokajaniu potrzeb rozwojowych dzieci z lekkim upośledzeniem umystowym - działania stosowane i postulowane. Kraków: Oficyna Wydawnicza „Impuls”.

Sołtys-Chmielowicz, A. (2002). Wady wymowy i ich korygowanie. Logopedia, 31, 53-93.

Sołtys-Chmielowicz, A. (2008). Zaburzenia artykulacji. Teoria i praktyka. Kraków: Oficyna Wydawnicza „Impuls”.

Sołtys-Chmielowicz, A. (2012). Klasyfikacje zaburzeń wymowy. In: Grabias, S., Kurkowski, M. (Eds.) Logopedia. Teoria zaburzeń mowy (pp. 417-429). Lublin: Wydawnictwo Uniwersytetu Marii Curie-Skłodowskiej.

Surowaniec, J. (1993). Metodyka postępowania logopedycznego w przypadku dyslalii. In: Gałkowski, T., et al. (Eds.) Diagnoza i terapia zaburzeń mowy (pp. 101-110). Lublin: Wydawnictwo Uniwersytetu Marii Curie-Skłodowskiej. 
Aleksandra Siedlaczek-Szwed, Agata Jałowiecka-Frania. Supporting Families in Correcting Dyslalia in Children

Zalewski, J. (2009). Trudne rodzicielstwo. In: Brejak, W., Zabłocki, K.J. (Eds.) Wczesna diagnoza $i$ wspomaganie rozwoju dziecka z dysfunkcjami (pp. 176-185). Warszawa: Stowarzyszenie Dobra Wola OPP. 